10. nodala

\title{
Inovāciju pārnese skolā un starp skolām
}

\author{
Līga Čakāne, Anete Butkēviča
}

Lai arī katrai skolai ir savas iekšèjās kultūras īpatnības, skolotāju un vadības sagatavotība, prioritātes, problēmas un atškirīgā vide, lielākajā daḷā skolu, kad tajās tiek ieviestas pārmaiṇas, notiek viens un tas pats ietekmes cikls. Ietekmes ciklam ir piecas komponentes: 1) kas ir sasniedzamais rezultāts, kā tas izskatās, ko tas nozīmē; 2) kādas ir skolotāju profesionālās pilnveides vajadzības saistībā ar šo sasniedzamo rezultātu; 3) kas ir nepieciešamās darbības un uzvedība, lai ieviestu vēlamās izmaiņas; 4) kā var gūt pierādījumus tam, ka pašreizējā mācīšana ietekmē skolēnu mācīšanās rezultātus; 5) pirmo četru soḷu izskatīšana - kur esam savā attīstībā, un kā rīkoties turpmāk (Hattie, Masters, \& Birch, 2015). Šìs sastāvdaḷas tiek papildinātas ar attiecīgajām skolas procesu pārvaldes jomām un

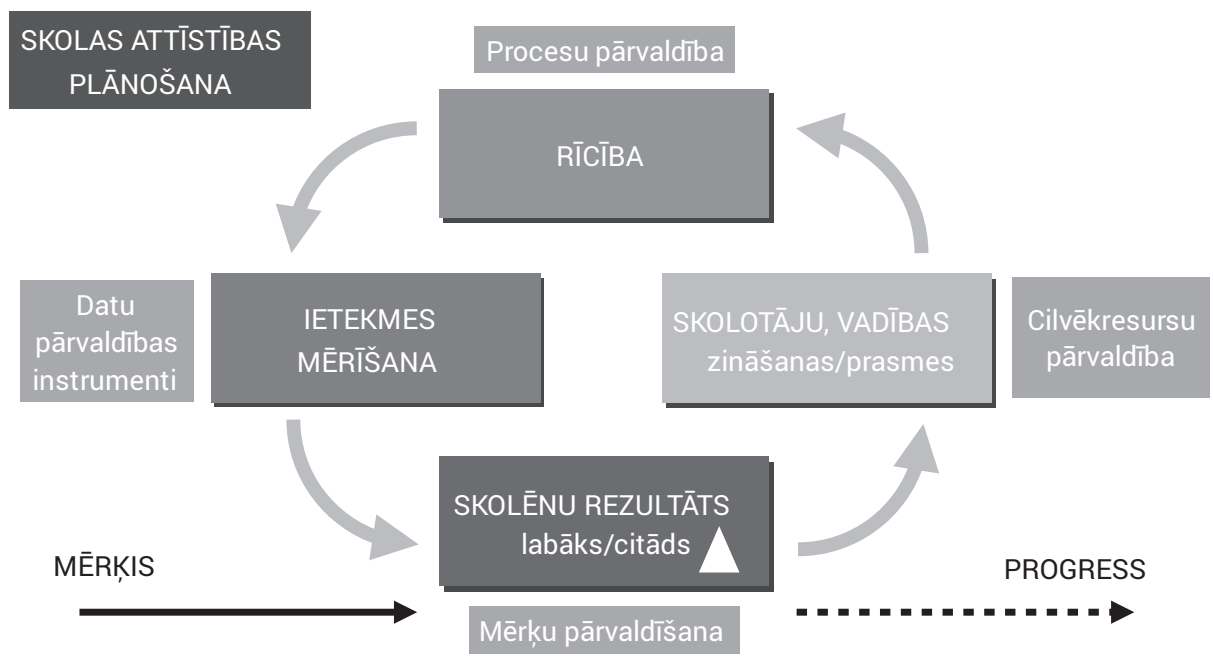

1. attēls. letekmes cikls izvirzīto mērḳu sasniegšanā skolā 
skolas attīstîbu, kas notiek, izvirzot mērkịi, piedzīvojot ietekmes ciklu tā sasniegšanā (skat. 1. attēlu).

Šajā nodaļā tiks apskatìts, kāda loma ir dažādiem izglìtības sistēmas līmeņiem un to dalïbnieku darbībām, lai skolā ieviestu skolotāju profesionālai pilnveidei nepieciešamas inovācijas un lai tās tiktu pārnestas starp citām skolām.

\section{Inovācijas jēdziens skolu izglītības kontekstā}

Inovācija ir jauna ideja, sociāla prakse vai objekts. Inovāciju pieņemšana saistās ar augstu sarežgìitibas līmeni, neziṇu, diskomfortu un riskiem, tāpēc nepieciešamas mērḳtiecīgas darbības, kas vērstas uz inovāciju izzināšanu (Rogers, 2003). Atbilstoša atbalsta trūkums ir visbūtiskākais iemesls, kāpēc kāda inovācija netiek pieñemta un ieviesta (Mulgan, 2006).

Jauns mācību saturs, jaunas pieejas skolēnu rezultātu vērtēšanā un pedagogisko uzskatu maiņa ir daži inovāciju piemēri skolu kontekstā. Izmaiņas skolas kopienas dalībnieku uzskatos un izpratnē ir pamats, lai sasniegtu ilgstošas pārmaiņas izglìtībā. Ar pašu ieviestām un pārvaldītām inovācijām saistās lielāka apñēmība un lielākas iespējas, ka šìs inovācijas nostiprināsies ilgtermiṇā (Huberman, 1983; Fullan, 2007). Šì brīža inovācija izglìitỉā Latvijā ir tādas mācišanas un mācīšanās iedibināšana skolu ikdienas praksē, kas atbilst 21 . gadsimta vajadzībām, kas rezultējas ar skolēna kompetenci.

Inovācijas var tikt definētas kā nepārtraukts process, kas vērsts uz attīstību (Nicholls, Simon, Gabriel, \& Whelan, 2015). Arī šì brǐža inovācija izglìīibā Latvijā uzskatāma par pakāpenisku, jo tā turpina virzību, kas iezīmējās jau 1998. un 2006. gadā ar pārmain̄ām izglìtibas saturā.

\section{Inovāciju ieviešana un pārnese skolotāja darbību līmenī}

Skolu attīstības literatūrā nostiprinājusies tēze, ka skolotāji ir svarīgākais ķēdes posms, lai realizētu inovatīvas pārmaiņas izglìtībā, un ka viṇi ir pārmaiņu aǵenti. Pirmais, kas ieviesa jēdzienu "pārmainu aǵenti" sakarā ar pārmaiņām skolu izglìtībā, bija Maikls Fulans (1993). Pēc viņa domām, skolotājiem jāveic tādas darbības, kas ieviestu vispārējus uzlabojumus izglītībā. Tieši skolotāji ir inovāciju radītāji, ieviesēji, tas aktualizē skolotāju līderu lomu.

Skolotāji līderi uztver sevi kā aktīvus zināšanu radītājus, nevis tikai informācijas saṇēmējus, kā arī kā nozīmes radītājus, identificējot un pastiprinot savu profesionālo balsi (Taylor et al., 2011). Tiek uzskatīts, ka viena no skolotāju līderu lomām ir būt par inovāciju ieviesējiem (Lieberman, \& Miller, 2004). Skolotāji 
līderi kā inovāciju ieviesēji ir aktīvi darītāji, nevis tikai domātāji. Skolu kontekstā skolotāji līderi ir lietas kursā par inovatīvām mācību pieejām, kuras tie, piemēram, ir iemācījušies no pētijumiem, kas var būt viens no vinu kā līderu uzdevumiem (Frost, 2012).

Skolotāju līderu darbība ir process, kurā skolotāji individuāli vai kolektīvi ietekmē citus kolēgus, skolas vadỉbu un citus skolas kopienas locekḷus, lai uzlabotu mācišanas un mācišanās praksi ar mērḳi uzlabot skolēnu mācīšanos un sasniegumus (York-Barr, \& Duke, 2004). Skolotāju līderība tiek definēta kā cilvēku mobilizācija, lai pieņemtu jaunas skolas prakses un pārliecības tā vārdā, lai katra skolēna mācīšanās un izaugsme tiktu optimizēta (Donaldson, 2006). Skolotāju līderībā ir jāuzsver koleg̣iālā dimensija, kas norāda uz sadarbību un abpusēju atbildību vienam pret otru (Frost, \& Durrant, 2003). Ja skolā ir tikai viens vai daži aktīvi skolotāji līderi, ar to nepietiek, lai visā skolā ieviestu inovācijas ilgstošām pārmaiņām. Skolai nepieciešama kopiena ar skolotājiem, kas vēlas sadarboties, ieviest un reflektēt par inovatīvām pārmaiņām (Hargreaves, \& Fullan, 2012).

Kā izpaužas skolotāju līderu darbība:

- skolotāji līderi pēta savu mācību praksi, radot dzilāāku izpratni par mācīšanu, mācišanos un mūžizglìtỉbas veidošanu;

- skolotāji ir atvērti dalīties ar savu izpratni par skolēniem, mācīšanos un mācišanu, tādējādi ietekmējot citus skolotājus un savas skolas sociālo vidi;

- skolotāji līderi atrod un rada iespējas vadìt citus un tajā pašā laikā uzturēt saikni ar mācību stundās notiekošo;

- skolotāji līderi mācās vadīt praktizējošu skolotāju kopienas, kas sekmē un atbalsta risku uzņemšanos un eksperimentēšanu. Tas rada drošu vidi profesionālai pilnveidei gan skolotājiem, kas ir iesācēji, gan pieredzējušiem skolotājiem;

- kad skolotāji ieņem līdera lomu, viṇi palīdz radīt piemērotu mācīšanās vidi, kura ietekmē visu skolas kopienu - gan skolotājus, gan skolēnus (Lieberman, \& Miller, 2005).

Skolotāju līderību Latvijā savā maǵistra darbā pētījusi Anete Butkeviča (2016). Viņa secina, ka Latvijas skolotāju līderu darbība ir cieši saistīta ar jaunu attiecību veidošanu, kuras mērḳis ir mācīties sadarbojoties un pilnveidot skolotāju profesionālo praksi. Skolotāji līderi apzinās nepieciešamību pēc uzlabojumiem viṇu un citu skolotāju mācību procesā. Intervijās atklājās skolotāju līderu motivācija un izpratne par nepieciešamību dalīties ar savu inovatīvo pieredzi savā skolā un ārpus tās. Efektīvākai inovāciju pārnesei nepieciešama pašiniciatīva. Skolotāju līderu izpratne par nepieciešamību pēc inovācijām un pārmaiņām veicina vinus iegūt daudzveidīgu un praktisku pieredzi, viņi izmēginina jaunus mācỉbu pañēmienus un uzlabo savu mācību darbu klasē. Intervētajiem skolotājiem 
līderiem ir divas būtiskas kopīgas īpašìbas - spēja radīt praksē balstītu pieredzi un radìt koleǵiālu vidi skolā.

Galvenais secinājums - mācišsanās kopiena skolā un ārpus tās rodas tikai tad, ja ir vairāki tādi skolotāji, jo dalīšanās ar pieredzi skolā veicina vidi, kas raksturīga mācišanās kopienai. Mācīšanās kopienā skolotāji var iegūt izpratni un atgriezenisko saiti par inovatīiām mācību metodēm, mācoties no savas un citu pieredzes, kas var veicināt uz uzlabojumiem virzîtu darbïbu. Tomēr ir nepieciešami vairāki šādi skolotāji, lai veidotu šādu vidi. Butkēviča (2016) analizē veidu, kā skolotāii līderi Latvijā sekmē inovāciju ieviešanu un pārnesi (skat. 2. attēlu).

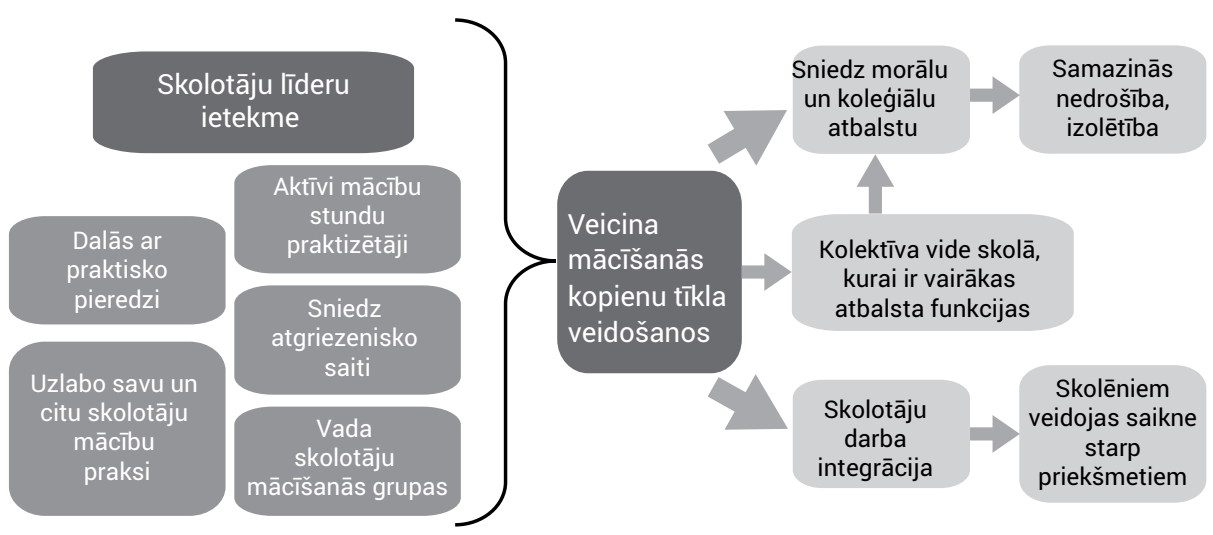

2. attēls. Skolotāju līderu darbība Latvijā (adaptēts pēc Butkēviča, 2016)

Skolotāju līderu darbības pieprasa attiecīgu atbalstu no skolas vadības. Skolas vadībai jāpamana un jāatbalsta skolotāji līderi; jāveicina pašvaldības atbalsts; jāpiesaista izglìtības eksperti vajadzību diagnosticēšanai, darbību plānošanai, skolotāju sadarbības modeḷu sākotnējai ieviešanai; jāplāno laiks un finansiālais atbalsts skolotāju sadarbības nodrošināšanai (Butkēviča, 2016).

Papildus skolotāju līderu lomai un dažādajām darbībām, kas veicina inovāciju rašanos un pārnesi skolās, atbilstošas profesionālās pilnveides un mācī̌nanās modeḷu ieviešana skolā arī tiek uzskatīta par svarīgu inovāciju ieviešanas aspektu skolā. Inovāciju ieviešanas mērḳis ir panākt pārmaiņu būtībai atbilstošas izmaiņas skolotāja darbībā. Tam var būt nepieciešama jaunu prasmju apguve. Skolotāja prasmes un attieksmi būtiski ietekmē tas, kāda veida profesionālās pilnveides iespējas ir pieejamas, kurās var regulāri iesaistìties. Ietekme panākama, iedzīvinot skolotāju mācišanās modeḷus, kuri balstìti reālā klases vidē un reāli, tūlìtēji ietekmē praksi (skat. arī 2. nodalı). 
Izmainas skolotāja praksē ir paliekošas, ja tās ir jau uzskatu līmenī - skolotājs ir pārliecinājies praksē par pieejas maiņas efektivitāti. Tāpēc nepieciešams izmantot tādas profesionālās pilnveides formas, kas panāk jaunas pieredzes izplatīšanu, aktīvu jaunā lietošanu ikdienas praksēe, refleksiju, kolēgu atbalstu. Pārmainas skolotāju uzskatos notiek primāri, kad tiek iegūti pierādījumi par skolēnu mācīšanās uzlabošanos. Ši uzlabošanās ir rezultāts skolotāja profesionālās mācīšanas pieeju izmaiņām, jaunam mācību saturam vai materiāliem vai atsevišķu darbību maiņām klasē (Guskey, 2002). Tieši veiksmīga pārmaiņu ieviešanas pieredze ir izšķirošais (skat. 3. attēlu).

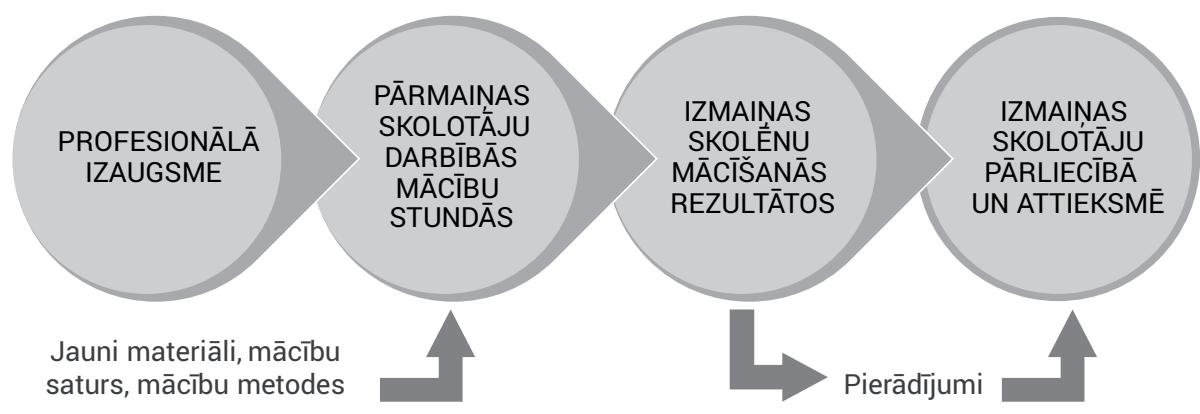

3. attēls. Izmainu saistība ar profesionālo izaugsmi (adaptēts pēc Guskey, 2002)

Vērojot skolotāju darbību un par to reflektējot, viena skolotāja pieredze var tikt pārnesta no klases uz klasi, redzot gan atsevišķus paņēmienus, kā to darìt, gan apliecinot konkrētas mācǐšanas pieejas iespējamību. Ja tam vēl pievienojas liecības par efektivitāti un ietekmi uz skolēna mācišanās rezultātiem ilgtermiņā, tad tas var sekmēt arī sākotnēji skeptisko, atturīgo skolotāju uzskatu maiṇu. Pārmaiņas mācību praksēs ir saistītas ar pārmaiņām attiecỉbā uz to, kādi ir skolēnu mācīšanās rezultāti, kāda ir skolotāju attieksme un uzskati (Guskey, 2002). Ne mazāk svarīgs aspekts ir skolotāju savstarpējās sadarbības treniņš - apzinoties, ka skolotāju cieša sadarbība ir viens no mūsdienu skolas kultūras neatṇemamiem elementiem. Sadarbība nepieciešama ne starp viena mācību priekšmeta skolotājiem, bet starp dažādu priekšmetu un jomu skolotājiem, kā arī starp skolotājiem konkrētā klasē, lai varētu efektīvi plānot un īstenot skolēnu dažādu, tostarp caurviju prasmju mācišanu, palīdzētu vinịiem veidot pārnesumu no viena mācību priekšmeta uz citu, uz reālās dzīves situācijām. Tas šobrīd ir ìpaši aktuāli, sekmējot kompetenci kā skolēna mācīšanās rezultātu.

Inovāciju izglìīibas jomā pētnieki norāda, ka skolās ir nepieciešama koleǵiāla vide (Saito, Murase, Ttsukui, \& Yeo, 2014). Skolotāju līderība veicina šādas vides rašanos (Crowther, 1997; Frost, \& Durrant, 2003; Fairman, \& Mackenzie, 2012). 
Mācīšanās kopienu tīkls un koleg̣iālā vide skolotājiem sniedz nepieciešamo atbalstu un drošības sajūtu eksperimentēt ar inovācijām. Pretstats šādai radošai un inovāciju pārneses veicinošai videi ir izolēts un atsvešināts skolotāja darbs, kas ir diezgan izplatīta parādība mūsdienu skolās. Skolotāju līderības darbības veicināšana varētu būt viens no veidiem, kā samazināt skolotāju profesijas izolētību (Shirley, \& Miller, 2016). Minētie profesionālās pilnveides pieeju piemēri arī saistās ar augsta līmeṇa skolotāju sadarbību. Stundu vērošana var veicināt arī skolas mācīšanās kopienas attīstību (Saito, Murase, Ttsukui, \& Yeo, 2014). Mācǐšanās kopiena var veidoties, ja vēroto stundu plāni tiek izplatīti ar citiem skolotājiem un ja tie tiek papildināti ar pašu skolotāju pierakstiem un refleksiju par stundā veiktajām un vērotajām darbībām. Papildus tam ieteicams pievienot arī skolēnu darba lapas un citus materiālus, kas ilustrē stundā veikto (Takahashi, \& Yoshida, 2004).

Ir vairāki veiksmīgi profesionālās pilnveides pieeju piemēri, kurus skolotāji var praktizēt. Stundu vērošana var veicināt lēmumu pieņemšanu, lai sāktu inovatīvu mācību pieeju praktizēšanu, kas kopīgas mācišanās cẹ̦ā izriet no racionālas empīisku pierādījumu izvērtēšanas (Young, 2009). Mācǐšanās no skolotājulīderu (kā inovāciju agrīno adaptētāju) reālās prakses ir empīiski pierādīta kā viens no faktoriem, kas paātrina inovāciju izplatišsanos (Young, \& Brown, 2016). Kopiga pierādījumu analīze - stundu vērošana un stundu video ierakstu vērošana un analīze, kas notiek starp vairāku skolu skolotājiem un vadību, liek kritiski pārvērtēt esošo zināšanu un uzskatu derīgumu. Tādējādi rodas jaunas darbības un tiek veicināts radošums (Ainscow et al., 2012). 2013. gadā Latvijā izveidotais "Inovatīvās pieredzes skolu tīkls" ir piemērs tam, kā var notikt inovāciju pārnese gan vienā skolā, gan starp skolām, un kurā aktīvi sadarbojas un mācās skolotāji līderi. Raksturīgākās skolotāju sadarbības formas skolās, kas veicina pārmaiṇu ieviešanu (skat. 4. attēlu), ir dažādu līmen̦u skolotāju sadarbības grupas, tostarp rīcỉbpētijumu grupas; savstarpēja stundu vērošana ar sekojošu stundas analīzi un atgriezenisko saiti kolēgim par viṇa profesionālo darbību stundā; sadarbība starp skolotājiem, plānojot un ìstenojot prasmju mācišanu konkrētas klases skolēniem. Ir daudz piemēru, kā skolas vadība vada, aprobē, līderē skolotāju savstarpējo mācǐšanos skolā, kā strādā skolotāji līderi, pulcējot ap sevi citus kolēgus.

Latvijā skolās pakāpeniski ienāk daudzveidīga, mērḳtiecīga skolotāju sadarbïba. Lai arī tā nav ikvienas skolas ikdiena, pozitīvie piemēri liecina, ka tas ir iespējams. Skolotāji ir gatavi iesaistìties un iedzị̣ināties, lai uzlabotu mācǐšanu un tādējādi arī mācišanos un skolēnu rezultātus. Praksē pārbaudīta arī ìpaša programma tieši skolotāju līderu grupas prasmju pilnveidei. Skolotāju līderības veicināšanas programmā skolotājiem bija jāsadarbojas ar citu skolu skolotājiem un jāielaiž viṇi savās mācību stundās, lai demonstrētu savas mācību pieejas. Šāda profesionālās pilnveides pieeja pierādījās kā efektīvs veids, kā skolotājos attīstīt 
līderības prasmes. Vēroto stundu analīze ir strukturēta veidā, lai uzsvērtu pozitīvo un ļautu skolotājam, kas vadījis stundu, izjust gandarījumu par sasniegto, kā arī lai paaugstinātu skolotāja efektivitāti un pārliecinātību. Pozitīvi iespaidi un sava snieguma apzināšanās ir labs veids, kā kḷūt par skolotāju lỉderi. Pētijumā veikto aptauju rezultāti rāda, ka arvien lielāks skaits skolotāju izsaka vēlmi kḷūt par līderiem (Namsone, Čakāne, \& Sarceviča-Kalviške, 2016).

Šādu un līdzīgu uz līderību vērstu profesionālās pilnveides modeḷu ieviešanai skolās nepieciešami vairāki faktori. Pirmais - ir nepieciešami entuziastiski skolotāji, kas vēlas iedziḷināties savā praksē un kuri sevi vēlas uzlūkot kā savas profesijas ekspertus. Otrs faktors ir uzticēšanās starp visām iesaistìtajām pusēm: starp skolotājiem savā skolā, no citām skolām, skolotāju un no ārpuses piesaistīto ekspertu savstarpējā uzticēšanās. Trešais faktors ir skolas vadības iesaiste. Skolotāji Latvijā ir norādījuši uz skolas vadības svarīgo lomu, nodrošinot iespējas skolotāju sadarbībai un praktisko problēmu risinājumam. Skolotāju mācīšanās rezultāti ir augstāki, ja skolas vadība darbojas kā mācību līderi, atbalsta skolotājus un veicina sadarbību (Namsone, Čakāne, \& Sarceviča-Kalviške, 2016, p. 219). Kopumā skolā jātiecas ieviest tādu sociālā kapitāla attīstību, kas vērsta uz līderību, uzticēšanos, kopīgo atbildību un sadarbību (Namsone, Čakāne, \& France, 2015, p. 234).

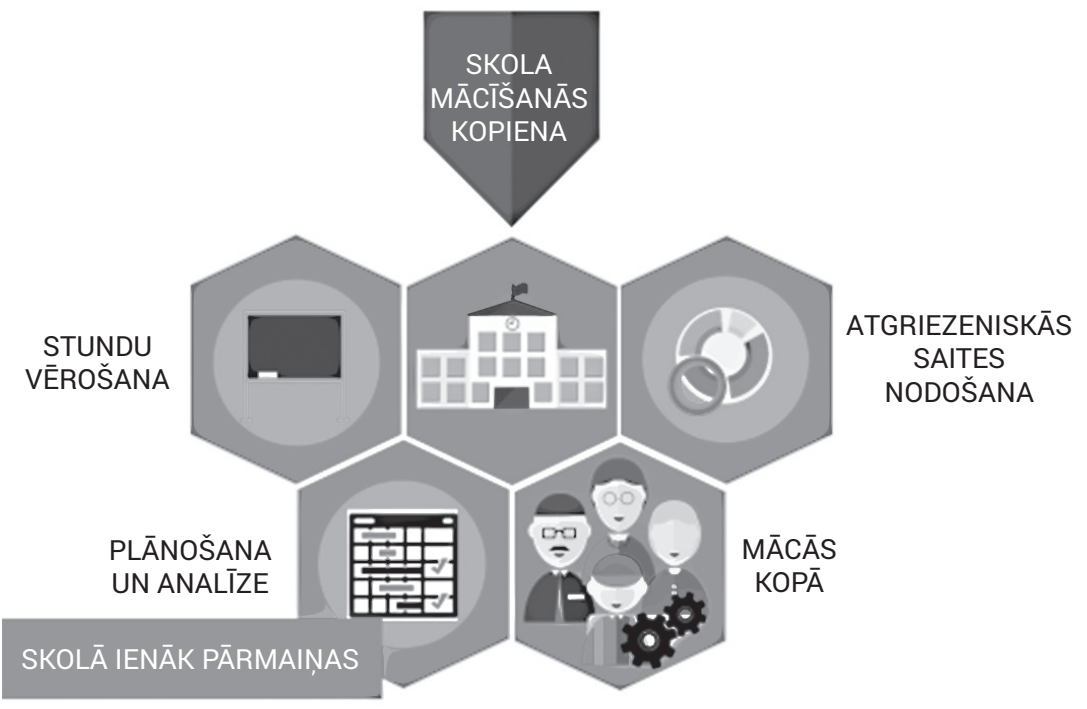

4. attēls. Pārmaiṇu ieviešana skolā: centrālie elementi (LU SIIC arhīvs) 
Daudzās skolās Latvijā ne tikai vārdos jau tiek atbalstīts uzskats, ka skolai ir jākḷūst par vietu, kur mācās arī skolotāji, ne tikai skolēni, kur skolotāji kopā strādā, lai uzlabotu mācīšanu un mācīšanos (Stigler, \& Hiebert, 2009).

\section{Skola kā mācīšanās kopiena: jēdziena apraksts un analīze}

Pārmaiņu mērḳis skolā ir sagaidāmā skolēnu snieguma uzlabošanās. Tiek izšķirti seši vienlīdz nozīmīgi pamatprincipi ceḷā uz rezultātu: skolas vadỉba ir mācīšanās līderi; skolotāji iesaista efektīvās mācībās katru skolēnu; skolotāju mācīšanās ir visefektīvākais cel̦šs, kā uzlabot skolēnu sniegumu; katram skolotājam un skolas vadībai pienākas mērḳtiecīga un regulāra atgriezeniskā saite; spēks ir sadarbībā. Dati ir kā informēts atspogul,ojums skolēniem, skolotājiem, skolas vadībai par situāciju, tie palīdz uzlabot skolotāju praksi (Hargreaves, \& Fullan, 2012).

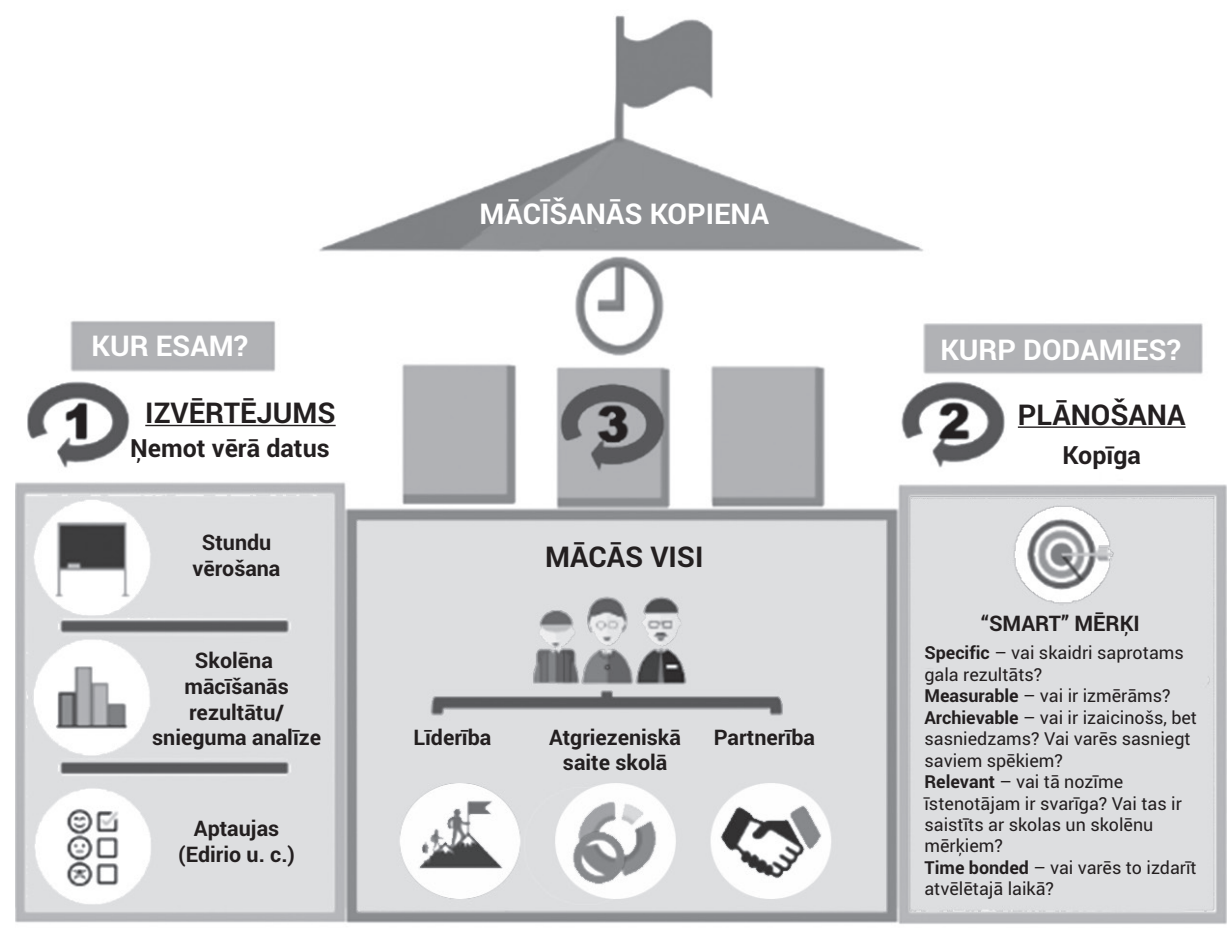

5. attēls. Skola kā mācīšanās kopiena (LU SIIC arhīvs) 
Tātad pārmaiņu ieviešanā skolā izšķiroša ir datos balstīta pārvaldība un plānošana un skolotāju un skolas vadības prasmes, profesionalitāte, kas pastāvīgi jāpilnveido. Tas atbilst priekšstatiem par skolu kā organizāciju, kurā visi mācās un nodrošina savstarpēju atgriezenisko saiti, lai sasniegtu maksimāli labu rezultātu. Lai pārmaiṇas notiktu, ir jābūt iniciatoriem. Tā var būt skolotāju grupa, kas analizē situāciju un ātri uztver nepieciešamo pārmainu būtību, ja skolas vadība ir pārmaiṇu līderi (skat. 4. un 5. attēlu).

\section{Datos balstītas izglītības pārvaldības loma}

Sākta pētniecība, kurā analizēti Latvijas skolu dokumenti (pašvērtējuma ziņojumi u. c.). Vērojama tendence, ka skolu dokumentos formulētie mērķi nereti ir nekonkrēti, grūti izmērāmi (Butkēviča, Zandbergs, Namsone, \& Briķe, 2018). Skolu (arī pašvaldību) veiktā rezultātu analīze bieži balstās tikai datos par skolēnu vidējiem rezultātiem summatīvajā vērtēšanā. Vairumā gadījumu iesaistītās puses nesaṇem noderīgu atgriezenisko saiti par viṇu rezultātiem un darbību kontekstā ar mērķu îstenošanu un turpmākās darbības koriḡěšanu.

Saistībā ar datu ieguvi un lietošanu skolas attīstībai tiek nošķirta divu veidu vērtēšana - skolēnu mācišanās rezultātu vērtēšana un skolotāju profesionalitātes vērtēšana. Skolas līmeņa attīstība tiek saistīta ar spēju objektīivi veikt šāda veida vērtēšanu, bet Latvijā tā diemžēl nav sistemātiski pilnveidota. OECD (the Organisation for Economic Co-operation and Development) uzsver, ka Latvijā ir nepieciešamība pēc jaunām stratēgiskām pieejām izglîtîbas procesu vērtēšanas ietvaram, kas aptver izglìīibas mērķus un skolēnu mācišanās uzlabošanu. Pašreizējā situācija nodrošina izglìtības vērtēšanu, kas ir fragmentāra. OECD norāda, ka drošu un ticamu datu un kontekstuālās informācijas pieeju vajadzētu uzlabot, un šajā nozīmē ir jācel̦ Izglīîibas un zinātnes ministrijas kapacitāte lietot datus un pētijjumus skolu attīstībai. N̦emot vērā pašreizējās reformas ieviestās konceptuālās izmaiņas, ir l̦oti aktuāli atbalstìt skolotāju spēju izvērtēt jaunā satura mācību mērḳus. Ministrijai nevajadzētu novērtēt par zemu šāda uzdevuma kompleksumu, ņemot vērā, ka Latvijas skolotājiem darba pieredze ir tikai ar zināšanās balstītu mācību saturu. Pašreizējā skolotāju vērtēšanas sistēma jāattīsta tālāk un jāvirza uz skolotāju profesionālās attīstības atbalstî̌šnu, tajā jāiesaista skolu līderi un vadība. Šo profesiju standartu aprakstā vajadzētu iekļaut to, kā precīzi izpaužas efektīvu skolotāju un skolas vadības attīstība. Šāda standarta saturs kalpo kā vadlīnijas vai uzziṇu palīglīdzeklis skolotājiem 
un skolas vadỉbai, kā dažādos karjeras posmos mācīties par savu profesionālo attīstîbu (OECD, 2016¹).

Skolu vadības prakse plaša spektra lēmumu pieṇemšanā balstìties uz datiem un šādas pieejas nozīmīgums skolas attīstībai uzsvērts pētījumos (Park, \& Datnow, 2009; Halverson, Grigg, Prichett, \& Thomas, 2007; Kowalski, Lasley, \& Mahoney, 2017). Uz izzināšanu/izpēti balstīta līderība atbalsta sistemātiskus pētỉjumus skolā, lai iegūtu datus par to, kā notiek mācišana un kādi ir rezultāti; reflektēt par tiem, kā uzlabot skolu (Stoll, Bolam, \& Collarbone, 2002; citēts Stoll et al., 2006). Mērījumu dati par skolas sniegumu un to publiskošana ievieš skaidrību, notiek jaunu zināšanu radīšana. Skolā pastāv sadarbības kultūra, skolas locekḷi kopā analizē rezultātus un plāno, kā tos uzlabot. Šādi rodas skaidrība par vērtībām, mērḳiem, turpmāko darbību virzību (Fullan, 1999).

Latvijā skolās pastiprinās interese par datiem, tos aizvien vairāk izmanto, lai iegūtu vispusīgu informāciju par rezultātiem. Tiek analizēti ne tikai valsts līmeņa pārbaudes darbu rezultāti. Skolu praksē ienāk skolotāju, skolēnu un vecāku viedokḷu noskaidrošana par skolai aktuāliem, ar mācibu procesa uzlabošanu saistītiem jautājumiem. ${ }^{2}$ Pieaugot dažādu skolas rīcībā esošo datu apjomam, aktualizējas jautājums par skolu vadības un skolotāju prasmēm kopā interpretēt, reflektēt un izmantot šo informāciju turpmākiem skolas attīstības mērḳiem (Halverson, Grigg, Prichett, \& Thomas, 2007).

Kombinēta dažādu datu analīze palīdz identificēt efektīvu skolu stratēgeiju. Dati par skolēnu rezultātiem būtu jāanalizē saistỉbā ar citiem datiem: skolotāju mācīšanas pañēmieniem, skolas vadības darbības rādītājiem. Dati jāorganizē tā, lai tie palīdzētu skolotājiem uzlabot savu praksi, skolā jāparedz speciāls laiks datu analīzei un lēmumu pieņemšanai (Shen, \& Cooley, 2008, Berhardt, 2013; u. c.) Lai skolā veidotos mācīšanās kopiena un inovāciju ieviešana, nepieciešams aktīvs un mērḳtiecīgs skolas vadības atbalsts.

\section{Skolas vadības loma}

Kolegiaāās vides veicināšana ir svarīga arī starp skolotājiem un skolas vadību. Tā tiek atzìta par skolas vides faktoru, kas var ietekmēt inovāciju ieviešanu skolās (Hargreaves, 2000). Skolotāji līderi ir labs atbalsts skolu vadībai. Skolās, kur vadība ien̦em nogaidošu pozīciju, viṇi var veicināt pārmaiṇu ieviešanu "no

1 OECD. (2016). Education in Latvia, Reviews of National Policies for Education, OECD Publishing, Paris. http://dx.doi.org/10.1787/9789264250628-en

2 Skat. piemēram, EDURIO piedāvātās darbības EDURIO. (2018). Quality monitoring for school systems. Pieejams: https://edurio.com/ (aplūkots 10.02.2018.). 
apakšas". Kā aptaujās norāda paši skolotāji, tas gan var būt l̦oti apgrūtinoši, jo kā skolotāju sadarbības priekšnosacijums tiek minēts tieši skolas vadības atbalsts (Namsone, Čakāne, \& Sarceviča-Kalviške, 2016).

Tas, kā skolā tiek analizēti dati, plānota attīstība, sekots progresam, sniedzot nepieciešamo atbalstu skolēniem un skolotājiem, ir atkarīgs no skolas vadības komandas, pirmām kārtām, no skolas direktora, viṇa prasmēm un uzskatiem. Kopīgas vērtïbas un vienota mērḳtiecība tiek atzītas par svarīgiem faktoriem (Andrews, \& Lewis, 2007). Skolas pārstāvji ar vecākiem vienojas, kādi skolēnu mācīšanās mērḳi ir jāizvirza un kā izpaužas kvalitatīvs skolotāju darbs, kā kopumā skolas darbība var tikt strukturēta, lai uzlabotu skolēnu mācǐšanos. Stratēgijas fokuss ir pievērsties izglītības instrumentiem, nevis tiešām regulām (Bryk et al., 1998; citēts Fullan, 1999).

Skolu vadības lomas būtiskums izkristalizējas vairākos Latvijas Universitātes Starpnozaru izglìtības inovāciju centra (LU SIIC) pētỉjumos. Ir pamats domāt, ka rezultātu atškirīibas starp skolām nevar tikt skaidrotas, balstoties tikai uz skolotāju profesionalitāti. Skolu vadībai un līerībai arī ir ietekme uz skolotāju komandu sniegumu (Namsone, \& Čakāne, 2017). Problēma liek meklēt risinājumus skolu vadības izglìtošanā, jo skolas līmenī inovāciju ieviešana primāri būs atkarīga tieši no skolu vadības izpratnes par pārmainu būtību un prasmēm motivēt un atbalstīt savus skolotājus.

Aktuāls jautājums Latvijas izglìtības sistēmā ir - kas kḷūst par skolas vadību? Kā norādìts (ETUCE, 2012³), nav valsts līmeņa regulējuma, kas to noteiktu. Tā ir pašvaldības kā skolas dibinātāja atbildība. L̦oti bieži skolas direktors uzṇēmies prioritāri saimnieciska rakstura problēmu risināšanu, atstājot mācību procesa vadību vietnieku ziṇā. Tas varētu būt daḷejji skaidrojams ar to, ka skolas vadībai nav formālu prasību tālākizglîtībai saistībā ar līderību un vadības zinībām (Daiktere, 2012). Arī vēsturiski Latvijas skolu vadības loma tika vairāk izprasta kā administratīva: resursu un procesu pārvaldība, neiesaistoties skolotāju profesionālās pilnveides jautājumos (Blūma, \& Daiktere, 2016, p. 157).

Skolu vadība atkarībā no savām darbībām var atainot dažādus līderības tipus (Brauckmann, \& Pashiardis, 2011). Katrs tips atspoguḷo daļu no iespējamajām darbībām, ko vadība var veikt, lai veicinātu inovāciju ieviešanu skolā un pārnesi starp skolām.

3 ETUCE. (2012). ETUCE School Leadership Survey Report: School Leadership in Europe: Issues, Challenges and Opportunities, European Trade Union Committee for Education, Brussels. Pieejams: www.csee-etuce.org/images/attachments/SchoolleadershipsurveyEn.pdf (aplūkots 01.12.2017.). 
Uzṇēmējdarbības stilam (Entrepreneurial style) raksturīgs, ka šie līderi radoši lieto ārējos tīklus un to piedāvātos resursus, lai sasniegtu skolas izvirzìto misiju. Notiek pozitīvu partnerību veidošana ar vecākiem, plašāku kopienu. Skolēniem to pamanot, uzlabojas viņu uzvedība. Ārējās vides apzināšanās un sadarbošanās ar apkārtējām skolām, sistēmām, kopienām, sabiedrību, uzṇēmumiem un valdības institūcijām. Pamatelementi: ārējo kontaktu iesaistī̌̌ana; stratēǵiska resursu piesaiste; attiecību veicināšana ar vecākiem un sabiedrību; sadarbība ar uzņēmumiem, organizācijām; nepieciešamo paņēmienu lietošana, lai iesaistītu minētās puses; skolas mērḳu pārrunāšana ar iesaistìtajām pusēm (stakeholders); skolas vīzijas komunicēšana sabiedrībai; abpusējas komunikācijas nodrošināšana; laba iespaida sniegšana par skolu kopienas acīs; uzticības būvēšana kopienā.

Mācību līderība (instructional style) izteikti fokusējas uz mācišanas un mācīšanās kvalitātes uzlabošanu un būvē skolas misiju un mērķus, kas saistīti ar mācišanu. Tie rada klimatu, kurā ir augstas prasības tam, kā notiek mācīšana un mācǐšanās, veic pārraudzību un izvērtēšanu. Nepārtraukti stimulē mācību inovācijas. Pamatelementi: mācību resursu nodrošināšana; augstāka līmeņa mācỉbu prakšu nodrošināšana; praktisku zināšanu lietošana; mācību pārraudzība; atgriezeniskās saites sniegšana skolotājiem; izvērtējumos iegūto datu lietošana, lai uzlabojumus ieviestu.

Partnerības līderība (participative style) norāda uz to, ka līderi organizē vadības aktivitātes caur citiem skolas darbiniekiem dažādos veidos atkarībā no vadības ieskatiem un atkarībā no skolas organizācijas kultūras. Viṇu līderības iespaidā notiek skolas darbinieku aktīva iesaistišanās lēmumu pieņemšanā un komandas nostiprināšanā. Šo līderu efektivitāte izpaužas, atbalstot skolotājus līderus, veicinot administratīivās komandas līderību, kas savukārt pozitīivi ietekmē skolas kā organizācijas mācīšanos (organizational learning) un skolotāju darbību. Skolas darbinieki izjūt izteiktāku apņemšanos sasniegt skolas organizatoriskos mērķus. Pamatelementi: sadarbības, apñēmības, atvērtas komunikācijas veicināšana; kopējas skolas misijas radīšana; aktīva skolas darbinieku iesaiste plānošanā, lēmumu pieṇemšanā, problēmu risināšanā; skolotāju mācību autonomija.

Personāla vadības un attīstības līderība (personnel development) raksturīga skolas līderiem, kuru pārliecība un darbība saistās ar skolotāju profesionālo izaugsmi un kas ietekmē skolotāju mācību praksi. Atbilstošu modelı,u, individuāla atbalsta un intelektuāla stimula nodrošināšana skolotājiem. Šādi skolas līderi veicina skolotāju profesionālo izaugsmi ar šādām darbībām: sniegšana, skolotāju profesionālās pilnveides vai kvalifikācijas celšanas (in-service training) nodrošināšana, profesionāla satura žurnālu nodrošināšana, ar mācībām saistītu inovāciju pārrunāšana kopīgās sanāksmēs. Pamatelementi: profesionālās pilnveides iedrošināšana; skolotāju apbalvošana, komplimentu un atzinības izteikšana par sasniegumiem; 
skolotāju panākumu atzīmēšana; informētu ieteikumu sniegšana personāla vadības attīstībai; informēšana par iespējām uzlabot zināšanas un prasmes.

Strukturējošā līderība (structuring style) saistās ar virzības un koordinēšanas nodrošināšanu skolā. Šie līderi uzṇemas atbildību par standartizētu procedūru un rutīnas uzturēšanu. Skolas objektu tehniskā apkope un uzturēšana, drošỉba. Skaidrības nodrošināšana par lomām, aktivitātēm, prioritātēm, skolēnu uzvedības normām, šo normu uzraudzīšana; kārtīguma nodrošināšana. Pamatelementi: skaidru likumu, noteikumu, procedūru konsekventa iedibināšana; disciplīna, kārtība.

Skolas vadības pamatdarbības inovāciju ieviešanā un pārnesē ir konkrētu mērḳu definēšana gan skolai kopumā, gan katram skolotājam; atbalsta nodrošināšana šo mērḳu sasniegšanā; sadarbības veicināšana, nodrošinot atbilstošas iespējas, aktivizējot pieredzes apmainu un cita veida mācišanās aktivitātes skolā. Vadībai jāiesaistās kopīgajās mācībās un jāseko līdzi jaunapgūtā ieviešanai reālā darbībā mācību stundās.

\section{Kā notiek inovāciju pārnese starp skolām Latvijā - līderības un motivācijas perspektīva}

Inovāciju pārnesei ārpus vienas skolas izšķiroša ir pašvaldības - skolu dibinātāja - loma un skolotāji līderi (pārmaiṇu ağenti), kuri spēj iedvesmot un dot reālu atbalstu ne tikai savas skolas skolotājiem, bet arī kolẹgiem citās skolās.

Pētijums par Latvijas skolotājiem līderiem parāda, ka skolotājs līderis iesaistās nepārtrauktā profesionālajā izaugsmē, analizē un reflektē, iedzịlinās, izrāda vēlmi mācìties kopā un vērot stundas. Skolotāji līderi nereti uzṇemas iniciatīvu vadīt darbnīcas, sniegt prezentācijas ārpus savas skolas un kopā plānot, analizēt, organizēt un izvērtēt aktivitātes savā skolā un novadā (Namsone, Čakāne, \& Sarceviča-Kalviške, 2016). Skolotāju līderu kustības veicināšanā izšḳiroša loma ir šo skolotāju pašu sākotnējai profesionālajai pilnveidei un turpmākajām pašu mācībām. Izveidotais vairāklīmeṇu skolu un skolotāju sadarbības tīkls un nacionālajā tîklā îstenotā skolotāju nepārtrauktās profesionālās pilnveides modelis paredz, ka reǵionālā tîklā skolotāji mācās paši (tostarp apgūst līderības prasmes), bet novada līmenī jau īsteno sevi kā līderi darbībā.

Skolas un skolotāju līderības pierādījums - skolas komanda pārnes un darbina savā novadā apgūtās idejas, daloties pieredzē ar novada skolām, kā arī pārnesot skolas komandas nacionālajā tỉklā iegūto pieredzi uz skolu kopumā. Skolotāju komandas skolās kopīgi plāno, ievieš un vērtē dažādas aktivitātes turpmākaji attīstībai un izplata idejas citu skolotāju vidū. Tīkla dalībnieku vidū ir 
savstarpēja uzticēšanās un atbalsts. Mācǐšanās notiek, vadot un piedaloties darbnīcās, semināros, apmainoties ar atbalsta materiāliem, vadot un vērojot mācību stundas. Tīklā iesaistītie skolotāji mācās cits no cita pieredzes reālā darba situācijās skolās ar fokusu uz darbībām mācību stundās. Galvenie faktori, kas ietekmē šo procesu, ir nepārtrauktas profesionālās pilnveides modeḷa darbināšana, pašas skolas organizēto pasākumu kvalitāte, skolas komandas saliedētība, skolas vadības atbalsts, laiks darbību un rezultātu ilgtspējai, skolotāja personiskās īpašības, pieredze (Namsone, Čakāne \& Sarceviča-Kalviške, 2016).

Par līderiem var kḷūt ne tikai atsevišksi skolotāji. Arī vienas skolas skolotāju grupa vai skola kopumā var kḷūt par līderskolu. Šādas skolas atbilstošās kvalitātes formulētas 1. tabulā (Namsone, Čakāne \& Sarceviča-Kalviške, 2016). Skola, kas iesaistījusies tīklā, var kḷūt par mācī̌anās klāstera centru citām skolām atbilstoši tam, kā to literatūrā par skolu kā mācišsanās kopienu klāsteriem apraksta citi autori (Hargreaves, \& Fullan, 2012). Daloties pieredzē novados, novada skolu skolotājiem ir radīta jaunas mācī̌sanās pieredzes iegūšanas iespējas, iesaistoties semināros ar mācību stundu vērošanu vai skolotāju sadarbības grupās. Skola uzskatāma par līderskolu, ja notiek mērḳtiecīgas, efektīvas, ilgtermiṇa skolotāju nepārtrauktas profesionālās pilnveides aktivitātes, kurās iesaistās lielākā dalıa skolotāju; notiek regulāra skolotāju sadarbība pārmaiṇu ieviešanā; notiek regulāra dalīšanās pieredzē ar citu skolu skolotājiem.

1. tabula. Kategorijas, kas raksturo līderskolu

\begin{tabular}{|c|c|c|}
\hline Kategorijas & Rādītāji & Piemēri, pierādījumi (skola x) \\
\hline \multirow[t]{4}{*}{ Mācīšanās kopiena } & Mērḳtiecīga & $\begin{array}{l}\text { Skolā organizēts mācību cikls visiem skolas } \\
\text { skolotājiem "Efektīva mācību stunda" u. c. }\end{array}$ \\
\hline & Efektīva & $\begin{array}{l}\text { Skolā ir rīcībpētījuma grupas, notiek savstarpēja } \\
\text { stundu vērošana un analīze }\end{array}$ \\
\hline & $\begin{array}{l}\text { Regulāra, } \\
\text { ilgtermin,a }\end{array}$ & $\begin{array}{l}\text { Mācīšanās grupas notiek katru mēnesi, noslēgumā } \\
\text { tiek organizēta konference; mācību semināri visiem } \\
\text { skolotājiem reizi semestrī }\end{array}$ \\
\hline & $\begin{array}{l}\text { lesaistās lielākā } \\
\text { dala skolotāju }\end{array}$ & $\begin{array}{l}26 \text { skolotāji iesaistījušies rīcībpētījuma grupās, } \\
\text { mācību semināros skolā piedalās visi skolotāji }\end{array}$ \\
\hline \multirow[t]{2}{*}{$\begin{array}{l}\text { Skola, kurā } \\
\text { sadarbojas }\end{array}$} & Mērḳtiecīga. & $\begin{array}{l}\text { Sadarbība starp kolēǵiem, kas fokusēta uz } \\
\text { uzlabojumiem, inovācijām, izmaiṇu ieviešanu }\end{array}$ \\
\hline & $\begin{array}{l}\text { Aptveroša, } \\
\text { ar tendenci } \\
\text { paplašināties }\end{array}$ & $\begin{array}{l}\text { Sadarbība tika sākta } 5 \text { kolēǵu komandā, tagad } \\
\text { aptver } 26 \text { kolēǵgus }\end{array}$ \\
\hline
\end{tabular}




\begin{tabular}{|c|c|c|}
\hline Kategorijas & Rādītāji & Piemēri, pierādījumi (skola $x$ ) \\
\hline \multirow[t]{2}{*}{$\begin{array}{l}\text { Notiek pārnese } \\
\text { (apliecina gatavību } \\
\text { dalīties pieredzē) }\end{array}$} & $\begin{array}{l}\text { Uzṇem kolēǵu } \\
\text { vizītes, organizēe } \\
\text { pasākumus }\end{array}$ & $\begin{array}{l}\text { Skolas x vietējā līmeña tīklā iesaistās vēl } \\
\text { septiṇas skolas; skola x dalās pieredzē kopš } \\
\text { 2011. gada }\end{array}$ \\
\hline & $\begin{array}{l}\text { Organizē } \\
\text { mācību } \\
\text { seminārus ar } \\
\text { stundu vērošanu } \\
\text { un analīzi citās } \\
\text { skolās }\end{array}$ & $\begin{array}{l}\text { Laikposmā no 2011. līdz 2013. gadam organizēja } \\
\text { vienu starptautisku, } 11 \text { nacionāla līmeña un } \\
24 \text { novadu līmeṇa darbnīcas un trīs skolas } \\
\text { lìmeña darbnīcas. }\end{array}$ \\
\hline
\end{tabular}

Mācīšanās līderi skolas kontekstā ir tie, kuriem izdodas uzlabot savu mācību praksi un palīdzēt citiem darìt to pašu (Fullan, 2011). Tìklošanās, lai sazinātos un sadarbotos ar kolēgiem, mācītos cits no cita un dalīšanās pieredzē vairāku skolu līmenī ir viena no skolotāju profesionālās pilnveides dimensijām (Zehetmeier, 2015; Craft, 2002).

Ir daudz labu piemēru, kā tiek īstenota skolotāju sadarbība ar mērķi sekmēt skolotāju profesionalitāti un inovāciju ieviešanu klasēs un skolās. Vairāk šādu piemēru ir par pārmain̄ām atseviškāa skolā, mazāk - pašvaldību iniciētu un vadìtu starpskolu model̦u. Pārņemamas prakses piemērs ir izglìtības politika pašvaldībā X, kur jau piecus gadus tiek īstenotas mērḳtiecīgas aktivitātes skolu un skolotāju profesionālai pilnveidei. Ir izveidojusies produktīva sadarbība gan skolā, gan starp skolām, ir izveidots metodiskais dienests, kurā iekḷauti skolotāji līderi, kuri spēj sniegt atbalstu mācišanas pilnveidošanā skolotajiem neatkarīgi no tā, kura mācību priekšmeta skolotāji viṇi ir. Lai gūtu drošus pierādījumus, apstiprinājumu šādu sadarbības modeḷu efektivitātei, ietekmei uz skolēnu mācīšanos ilgtermiņā, nepieciešams papildu pētijums - padzilināàta situācijas (procesu un rezultātu) analīze.

\section{Secinājumi}

Inovāciju ieviešana skolā un veiksmīga pārnese starp skolām ir dažādos līmeņos iesaistīto dalībnieku kopīga atbildība. Nepieciešamo pārmaiņu ieviešanu ikvienā skolā ietekmē skolotāju izpratne par inovāciju izraisīto pārmaiņu būtību. Skolotājiem ir būtiski izmēgeināt inovācijas praktiski un pārliecināties par izmaiņu efektivitāti jeb gūt pozitīvu pieredzi. Šādu pieredzi var gūt, iesaistoties profesionālās pilnveides darbībās, kas mērḳētas uz regulāru sadarbību un refleksiju, kā dēl mainās attieksme un uzskati. Šāda profesionālās pilnveides model̦a piemērs ir kopīgā stundu vērošana un analīze, kas var notikt ne tikai vienā skolā, bet arī 
starp vairāku skolu skolotāju komandām. Tas aktualizē jautājumu par spēju sadarboties un uzticēties kopīgā mācǐšanās procesā.

Skolotāju līderu darbība var kalpot kā pieeja skolām izmantot savus iekšējos cilvēkresursus skolotāju profesionālajā pilnveidē. Skolotāju līderu darbībā inovācijas tiek ieviestas skolā un tiek veicināta to pārnese starp skolotājiem un skolām. Tomēr jāṇem vērā, ka šādiem skolotājiem nepieciešama attiecīga koleg̣iāla vide jeb motivēti domubiedri, kas vēlas mācìties sadarbojoties, kā arī vadības atbalsts.

Skolas vadības līmenī inovāciju ieviešanu un pārnesi ietekmē vadības komandas un direktora izpratne un prasmes plānot inovāciju ieviešanu un vadīt šo procesu. Skolu vadībai jāfokusējas ne tikai uz saimnieciski organizatoriskām skolas pārvaldības funkcijām, bet arī uz mācību procesa uzlabošanas funkcijām.

Pārmaiņu ieviešana skolā lielā mērā ir atkarīga arī no datos balstìtas pārvaldības. Ietekmes cikls skolā sākas ar izvērtējumu, kādi skolā ir pierādījumi un dati par pašreizējo situāciju. No tā izriet plānošana un mērķu izvirziššna turpmākajai attīstībai. Nākamajā posmā atkal tiek veikts izvērtējums, vai ir notikušas vēlamās izmaiņas. Šāda ietekmes cikla uzturēšanai skolas vadībai ir nepieciešama datu pārvaldības un analīzes pratība, kā arī spēja iesaistìt visus skolas kopienas locekḷus mācǐšanās vajadzību identificēšanā. Tas atbilst koncepcijai par skolu kā mācīšanās kopienu, aktualizējot jautājumu, kā skolu veidot par organizāciju un kopienu, kurā visi mācās sadarbojoties un skolas vadība ir pārmaiņu līderis.

\section{Kā darbojas skola, kura izmanto pārmaiṇu dotās iespējas, lai rezultāti uzlabotos:}

- skolā radīta vienota izpratne par pārmaiņu būtỉbu, visu iesaiste mērḳu definēšanā un sasniegtā izvērtēšanā;

- mērķu izvirzišanai seko esošās situācijas analīze, izmantojot datus par mācību stundu kvalitāti un skolēnu sniegumu;

- skolas darba izvērtējums vienmēr ir samērots ar skolas konkrētajiem mērkiem. Tiek plānots, kādi dati ir skolā, vai tie ir pietiekami daudzpusīgi (mācību procesa vērojumi, aptaujas, skolēnu sniegums), kādus vēl nepieciešams iegūt, kā notiks analīze;

- ir nodrošināti nepieciešamie apstākḷi inovāciju ieviešanai, tostarp skolotāju sadarbībai plānot un analizēt mācišanu un mācišsanos, savstarpējai mācību stundu vērošanai un analīzei (vide, resursi, mācību procesa organizācija);

- skolas vadība strādā kā komanda, kas vienoti iet uz mērḳiem, spēj motivēt skolotājus, plāno skolotāju mācišanos. Skolas vadībai ir pilnīga izpratne (kas balstās datu analīzē) par katra skolotāja prasmēm un skolotājiem nepieciešamo atbalstu prasmju pilnveidē. Tiek izvirzīti individuālie mērksi katram skolotājam, notiek regulāras progresa sarunas. Tiek sniegts atbalsts individuālam skolotājam, palīdzot apgūt nepieciešamās prasmes. 


\section{IZMANTOTĀ LITERATŪRA}

Ainscow, M., Dyson, A., Goldrick, S., \& West, M. (2012). Making schools effective for all: rethinking the task. School Leadership \& Management, 32(3), pp. 197-213.

Andrews, D., \& Lewis, M. (2007). Transforming practice from within: The power of the professional learning community. In L. Stoll \& K.S. Louis (eds). Professional learning communities: Divergence, depth and dilemmas. Maidenhead: Open University Press.

Bluma, D., \& Daiktere, I. (2016). Latvia: School Principals and Leadership Research in Latvia. In A Decade of Research on School Principals (pp. 137-160). Springer International Publishing.

Brauckmann, S., \& Pashiardis, P. (2011). A validation study of the leadership styles of a holistic leadership theoretical framework. International Journal of Educational Management, 25(1), pp. 11-32.

Bryk, A., Sebring, P., Kerbow, D., Rollow, S., \& Easton, J. (1998) Charting Chicago School Reform, Boulder, CO, Westview Press.

Butkēviča, A. (2016). Dabaszinātņu un matemātikas skolotāji līderi kā sociālo inovāciju difūzijas aǵenti (Maǵistra darbs). Rīga: Latvijas Universitātes Sociālo zinātṇu fakultātes Sociologijas studiju nodaļa.

Butkēviča, A., Zandbergs, U., Namsone, D., \& Briķe, S. (2018). Exploring the input of competence assessment to goal-setting in various types of organizations. SOCIETY, INTEGRATION, EDUCATION 2018.

Craft, A. (2002). Continuing professional development: A practical guide for teachers and schools. Routledge.

Crowther, F. (1997). Teachers as leaders-an exploratory framework. International Journal of Educational Management, 11(1), pp. 6-13. http://dx.doi.org/10.1108/09513549710155410

Daiktere, I. (2012). Vispārizglītojošās skolas direktora loma skolas kultūras pilnveidē. Disertācija doktora grāda iegūšanai. Latvijas Universitāte.

Donaldson Jr, G. A. (2006). Cultivating leadership in schools: Connecting people, purpose, and practice ( $2^{\text {nd }}$ ed.). Teachers College Press.

Fairman, J. C., \& Mackenzie, S. V. (2012). Spheres of teacher leadership action for learning. Professional development in education, 38(2), pp. 229-246. DOI: 10.1080/19415257.2012. 657865

Frost, D. (2012). From professional development to system change: teacher leadership and innovation. Professional development in education, 38(2), pp. 205-227. DOI: 10.1080/ 19415257.2012.657861

Frost, D., \& Durrant, J. (2003). Teacher leadership: Rationale, strategy and impact. School Leadership \& Management, 23(2), pp. 173-186. DOI:10.1080/1363243032000091940

Fullan, M. (1993). Why teachers must become change agents. Educational leadership, 50, pp. $1-13$.

Fullan, M. (1999). Change forces: The sequel. Psychology Press.

Fullan, M. (2007). The new meaning of educational change ( $4^{\text {th }}$ ed.). Routledge.

Fullan, M. (2011). Change leader: Learning to do what matters most. John Wiley \& Sons.

Guskey, T. R. (2002). Professional development and teacher change. Teachers and teaching, 8(3), pp. 381-391. 
Halverson, R., Grigg, J., Prichett, R., \& Thomas, C. (2007). The new instructional leadership: Creating data-driven instructional systems in school. Journal of School Leadership, 17(2), p. 159.

Hargreaves, A. (2000). Contrived collegiality: The micropolitics of teacher collaboration. In Sociology of education: Major themes, 3. Taylor \& Francis Group.

Hargreaves, A., Fullan, M. (2012). Professional capital: Transforming teaching in every school. Teachers College Press.

Hattie, J., Masters, D., \& Birch, K. (2015). Visible learning into action: International case studies of impact. Routledge.

Huberman, M. (1983). The role of teacher education in the improvement of educational practice: A linkage model. European Journal of Teacher Education, 6(1), pp. 17-29.

Kowalski, T. J., Lasley II, T. J., \& Mahoney, J. W. (2017). Data-driven decisions and school leadership: Best practices for school improvement. Pearson.

Lieberman, A., \& Miller, L. (2004). Teacher leadership. San Francisco: Jossey-Bass.

Lieberman, A., \& Miller, L. (2005). Teachers as leaders. In The Educational Forum 69(2), (pp. 151-162). Taylor \& Francis Group.

Mulgan, G. (2006). The process of social innovation. Innovations, 1(2), pp. 145-162. doi:10.1162/itgg.2006.1.2.145

Namsone, D., Čakāne, L. (2017). How primary school teachers succeed in designing lessons to teach students $21^{\text {st }}$ century skills. $12^{\text {th }}$ Conference of the European Science Education Research Association (ESERA), 21-25.08.2017. Dublin, Ireland.

Namsone, D., Čakāne, L., \& France, I. (2015). How science teachers learn to reflect by analyzing jointly observed lessons. LUMAT, 3(2), pp. 223-236. Pieejams: http://www. luma.fi/lumat-en/385 (aplūkots 01.12.2017.).

Namsone, D., Čakāne, L., \& Sarceviča-Kalviške, D. (2016). Teacher Teams and Schools Become Leaders to Disseminate Innovative Practice. SOCIETY. INTEGRATION. EDUCATION. Proceedings of the International Scientific Conference, 2016. Volume II, (pp. 208-222). Rezekne: Rezeknes Academy of Technologies. DOI: http://dx.doi.org/10.17770/sie2016 vol2.1393.

Nicholls, A., Simon, J., Gabriel, M., \& Whelan, C. (eds.). (2015). New frontiers in social innovation research. Springer.

Park, V., \& Datnow, A. (2009). Co-constructing distributed leadership: District and school connections in data-driven decision-making. School leadership and Management, 29(5), pp. 477-494.

Rogers, E. M. (2003). Diffusion of innovations ( $5^{\text {th }}$ ed.). New York: Free Press.

Saito, E., Murase, M., Tsukui, A., \& Yeo, J. (2014). Lesson Study for Learning Community: A Guide to Sustainable School Reform. Routledge.

Shen, J., \& Cooley, V. E. (2008.) Critical issues in using data for decision-making. International Journal of Leadership in Education.

Shirley, D., \& Miller, A. F. (2016). The labyrinth of teacher leadership. Journal of Educational Change, 17(1), pp. 1-5.

Stigler, J. W., \& Hiebert, J. (2009). Closing the teaching gap. Phi Delta Kappan, 91(3), pp. 32-37.

Stoll, L., Bolam, R. \& Collarbone, P. (2002). Leading for change: Building capacity for learning. In Leithwood, K., \& Hallinger, P. (eds). Second international handbook of educational leadership and administration, Dordrecht: Kluwer. 
Stoll, L., Bolam, R., McMahon, A., Wallace, M., \& Thomas, S. (2006). Professional learning communities: A review of the literature. Journal of educational change, 7(4), pp. 221-258.

Takahashi, A., \& Yoshida, M. (2004). Lesson-study communities. Teaching children mathematics, 10(9), pp. 436-437.

Taylor, M., Goeke, J., Klein, E., Onore, C., \& Geist, K. (2011). Changing leadership: Teachers lead the way for schools that learn. Teaching and teacher education, 27(5), pp. 920-929. doi:10.1016/j.tate.2011.03.003

York-Barr, J., \& Duke, K. (2004). What do we know about teacher leadership? Findings fromtwo decades of scholarship. Review of educational research, 74(3), pp. 255-316. doi:10.3102/00346543074003255

Young, H. P. (2009). Innovation diffusion in heterogeneous populations: Contagion, socialinfluence, and social learning. The American economic review, pp. 1899-1924.

Young, H. P., \& Brown, L. M. (2016). The Diffusion of a Social Innovation: Executive Stock Options from 1936-2005 (777).

Zehetmeier, S., Andreitz, I., Erlacher, W., \& Rauch, F. (2015). Researching the impact of teacher professional development programmes based on action research, constructivism, and systems theory. Educational action research, 23(2), pp. 162-177. 